\title{
A preliminary evaluation of lake morphometric traits influence on the maximum colonization depth of aquatic plants
}

\author{
Mattia M. AZZELLA, ${ }^{1}$ Rossano BOLPAGNI, ${ }^{2 *}$ Alessandro OGGIONI ${ }^{3}$ \\ ${ }^{1}$ Department of Environmental Biology, La Sapienza University of Rome, P.le Aldo Moro 5, 00185, Rome; ${ }^{2}$ Department of Life Sciences, \\ University of Parma, V.le Usberti 11/A, 43124, Parma; ${ }^{3}$ Institute for Electromagnetic Sensing of the Environment, National Research \\ Council, CNR-IREA, Via Bassini 15, 20133 Milan, Italy \\ *Corresponding author: rossano.bolpagni@unipr.it
}

\begin{abstract}
Underwater light regime is widely considered the principal determinant of aquatic plant depth distribution. The majority of previous studies dealing with macrophytes in lakes have singled out Secchi disk transparency (SD) values as the key empirical proxy to explain the maximum depth of macrophyte colonization $(\mathrm{Zc})$. Few studies have investigated the role played by lake morphometry in structuring macrophyte beds. Using a balanced dataset including 20 Italian lakes (10 shallow and 10 deep lakes), we analysed transparency and lake morphometric traits to investigate their possible effects on Zc. Our results demonstrate that lake area plays a significant role, and confirm a direct influence of SD values on Zc. Considering lakes with an equal degree of transparency, smaller lakes may yield a lower Zc than larger ones. Morphology has a great influence on lake ecological characteristics especially on water thermal conditions and mixing depth. Based on our data, we argue that the thermal stratification plays a non negligible role in explaining macrophytes zonation, due to its influence on macrophytes life cycles and phytoplankton vertical distribution. Therefore, the present data suggest the need to enhance and refine our knowledge about the relationship between aquatic plants distribution and lake thermal conditions to better model the response of macrophytes to climate change and eutrophication.
\end{abstract}

Key words: submerged aquatic plants, maximum growing depth, Secchi disk transparency, lake area, littoral slope.

Received: December 2013. Accepted: January 2014.

\section{INTRODUCTION}

Macrophytes are a key element of aquatic ecosystems since they play a central role in nutrient cycling, primary production, increasing habitat heterogeneity and sustaining biodiversity (Carpenter and Lodge, 1986). During the last century, aquatic plants have experienced a widespread decline and a marked decrease in diversity and representativeness, especially in developed countries (Schmieder, 2004; Dudgeon et al., 2006; Bolpagni et al., 2013a). Eutrophication and water over-exploitation, land use changes and littoral and shoreline modifications are the main factors forwarding critical regime shifts in aquatic primary producers that have promoted the replacement of submerged plant species by pleustophytes or phytoplankton (Scheffer et al., 2003; Bolpagni et al., 2007, 2013b, 2014; Sayer et al., 2010; Azzella et al., 2013a, 2014; Tombolini et al., 2014).

In lakes, the availability of light and the underwater light regime are widely considered the principal factors controlling macrophyte growth along the depth gradient (Middelboe and Markager, 1997; Hudon et al., 2000; Schwarz et al., 2000). The majority of previous studies have assessed the aquatic plant zonation using the Secchi disk transparency (SD), as a strong empirical factor explaining the maximum depth of colonization (Zc) (Mid- delboe and Markager, 1997; Schwarz et al., 2000). Other factors (e.g., pressure, water temperature, latitude) are generally considered to be of minor importance. However, the non-linear relationship between $\mathrm{SD}$ and $\mathrm{Zc}$ and the marked variability that characterizes the maximum depths of macrophyte colonization in lakes with similar water transparency suggest that various factors may influence the depth attained by macrophytes (Middelboe and Markager, 1997), and in particular the size and depth of a water body. Hence, there are presumably several factors related to a lake's morphometry that may influence aquatic plant life and dispersal, including water-table fluctuations, water circulation and temperature patterns, wind exposure and fetch (Bornette and Puijalon, 2011 and references therein). The aim of our work was to investigate the role of lake morphology as a predictor of the depth distribution of macrophytes assuming a dependence of $\mathrm{Zc}$ on morphometric characteristics. Thus, we expected a significant increase in $\mathrm{Zc}$ in proportion to the lake area under comparable water transparency conditions, as observed in field surveys.

We analyzed the correlation between the Zc, SD and lake morphology of 20 Italian lakes using a balanced dataset in terms of the lakes' mean depth (10 shallow and 10 deep lakes, in accordance with Carvalho et al., 2009). In particular, our work was designed to evaluate i) Zc vari- 
ability in relation to the SD, and ii) the role of lake area in driving Zc.

\section{METHODS}

Data of Zc, SD and morphological features of 20 Italian lakes were extracted from a broader dataset of 29 lakes using a balanced approach that represents an innovative viewpoint in the analysis of the Zc, never used before. Generally, in a field experiment it is of primary importance to consider heterogeneous pools of data not biased toward any particular habitat typology to obtain robust results. For example using a database with a high number of shallow lakes in spite of deep lakes, as usually happens, given that the shallow lakes are much more widespread than deep ones. Therefore, we first distinguished shallow lakes from deep lakes, according to the method used by Carvalho et al. (2009), who considered lakes with a mean depth $>15 \mathrm{~m}$ as deep. We then selected an equal number of shallow and deep lakes (10) (Fig. 1) in order to ensure that the datasets were not biased towards shallow or deep lakes (Tab. 1). In the period 20092010, Zc data were collected using transects performed along depth gradient in agreement with Bolpagni (2013), Oggioni et al. (2013) and Azzella et al. (2013b). The number of transects, which varied according to the size of the lakes, ranged from 9 (Lago Grande) to 41 (Garda); this was sufficient to avoid a sample-based bias in the evaluation of Zc (Spears et al., 2009). Over the same period, SD data were collected both during winter circulation (January/February) and at the end of the summer stratification (August). Unlike other studies that based their analysis exclusively on the summer SD data, our model considered the annual mean SD value. Littoral slopes were determined using field measurements, as the ratio of $\mathrm{Zc}$ and its linear distance from the shoreline. Collection of Zc, SD and littoral slope data was supported by the MONECOLA project, the Regional Agency for Environmental Protection (ARPA Lombardia), the Provincial Agency for Environmental Protection of Trento (APPA), and three research institutes (La Sapienza University, University of Parma, the National Research Council - CNR). Total phosphorus concentrations (TP) and total alkalinity (Alk) values were obtained from the ARPA Lombardia database (unpublished data) and Azzella et al. (2013b). Macrophytes nomenclature follows Bazzichelli and Abdelahad (2009) for charophytes and Conti et al. (2005) for vascular species.

We performed a regression analysis using linear models to assess the relationship between SD and Zc. The Akaike Information Criterion (AIC) was used to select the most suitable model to explain the correlation (Akaike, 1974). A multiple regression analysis was instead applied to select the morphological variables that affect Zc. A preliminary

Tab. 1. Main features of the study lakes.

\begin{tabular}{|c|c|c|c|c|c|c|c|c|c|c|c|}
\hline Lake & $\begin{array}{c}\mathrm{Al} \\
\mathrm{m} \text { asl }\end{array}$ & $\begin{array}{c}\mathrm{V} \\
\mathrm{km}^{3}\end{array}$ & $\begin{array}{c}\mathrm{A} \\
\mathrm{km}^{2}\end{array}$ & $\underset{\mathrm{m}}{\mathrm{Zmax}}$ & $\begin{array}{c}\text { Zmean } \\
\mathrm{m}\end{array}$ & $\begin{array}{l}\mathrm{S} \\
\%\end{array}$ & $\begin{array}{l}\mathrm{Zc} \\
\mathrm{M}\end{array}$ & $\begin{array}{c}\mathrm{SD} \\
\mathrm{m}\end{array}$ & $\begin{array}{c}\text { TP } \\
\mu g \mathrm{P} \mathrm{L}^{-1}\end{array}$ & $\begin{array}{c}\text { Alk } \\
\mu \text { eq } L^{-1}\end{array}$ & Deepest macrophyte \\
\hline Albano & 293 & 0.5 & 6.0 & 170.0 & 77.1 & 36.8 & 11.0 & 6.2 & 21.6 & 3606.6 & Cha_glo \\
\hline Alserio & 243 & 0.0 & 1.2 & 8.0 & 5.4 & 7.8 & 3.0 & 2.0 & 70.0 & 3670.0 & Cer_dem \\
\hline Bolsena & 305 & 8.9 & 114.5 & 146.0 & 77.9 & 5.0 & 20.0 & 11.8 & 17.2 & 4124.1 & Nit_opa \\
\hline Bracciano & 164 & 5.0 & 57.5 & 160.0 & 86.1 & 9.9 & 26.0 & 12.8 & 14.2 & 3263.0 & Nit_opa \\
\hline Candia & 226 & 0.0 & 1.7 & 8.0 & 5.9 & 9.1 & 4.0 & 4.0 & 40.0 & 1080.0 & Tra_nat/Nym_pel/Naj_mar \\
\hline Como & 198 & 22.5 & 145.9 & 410.0 & 154.2 & 83.1 & 14.6 & 12.0 & 38.6 & 1190.0 & Cha_glo/Cer_dem \\
\hline Garda & 65 & 49.0 & 370.0 & 346.0 & 132.0 & 35.4 & 17.5 & 10.0 & 19.0 & 2120.0 & Cha_glo \\
\hline Idro & 368 & 0.9 & 11.0 & 124.0 & 77.0 & 36 & 10.5 & 3.7 & 91.5 & 2485.0 & Cha_glo \\
\hline Iseo & 186 & 7.6 & 60.9 & 251.0 & 124.8 & 62.7 & 8.5 & 3.0 & 50.0 & 1900.0 & Cha_glo \\
\hline Lago Grande & 656 & 0.0 & 0.4 & 35.0 & 8.2 & 9.1 & 3.30 & 1.3 & 123.6 & 3369.4 & Cer_dem/Tra_nat \\
\hline Mantova Superiore & 15 & 0.0 & 1.5 & 9.0 & 2.7 & 3.1 & 4.0 & 0.8 & 91.7 & 2643.5 & Cer_dem/Tra_nat \\
\hline Mantova Mezzo & 15 & 0.0 & 1.1 & 15.0 & 2.7 & 3.3 & 3.5 & 0.8 & 60.8 & 2657.7 & Cer_dem/Nel_nuc \\
\hline Mantova Inferiore & 18 & 0.0 & 3.7 & 12.0 & 4.1 & 4.0 & 3.5 & 0.8 & 91.1 & 2643.1 & Cer_dem \\
\hline Monate & 266 & 0.0 & 2.5 & 34.1 & 18.3 & 62.7 & 8.5 & 9.0 & 6.0 & 830.0 & Cer_dem \\
\hline Nemi & 318 & 0.0 & 1.7 & 34.0 & 19.5 & 41.1 & 8.0 & 5.8 & 34.0 & 2258.3 & Cha_glo \\
\hline Segrino & 374 & 0.0 & 0.3 & 8.6 & 4.3 & 10.2 & 4.3 & 2.6 & 12.0 & 2920.0 & Myr_spi \\
\hline Varese & 238 & 0.2 & 14.8 & 26.0 & 11.0 & 6.2 & 3.5 & 1.7 & 25.0 & 2270.0 & Cer_dem/Naj_mar \\
\hline Viverone & 230 & 0.1 & 5.8 & 50.0 & 21.7 & 2.6 & 7.1 & 4.0 & 92.0 & 1060.0 & Cer_dem \\
\hline Endine & 334 & 0.0 & 2.1 & 9.4 & 5.6 & 24.1 & 6.0 & 4.1 & 12.0 & 3730.0 & Cer_dem \\
\hline Levico & 440 & 0.0 & 1.2 & 38.0 & 11.0 & 2.1 & 5.0 & 7.5 & 29.0 & 1260.0 & Cer_dem \\
\hline
\end{tabular}

Al, altitude; $V$, volume; $A$, area; Zmax, maximum depth; Zmean, mean depth; $S$, slope; Zc, maximum depth of macrophyte colonization; SD, Secchi disk transparency; TP, total phosphorous; Alk, total alkalinity; deepest macrophytes, the plant species at the maximum colonization depth. Cha glo, Chara globularis Thuillier 1799; Cer dem, Ceratophyllum demersum L.; Nit opa, Nitella opaca (C. Agardh ex Bruzelius) C. Agardh. 1824; Tra nat, Trapa natans L.; Nym pel, Nymphoides peltata (S.G. Gmel.) Kuntze; Naj mar, Najas marina L. ssp. marina; Nel nuc, Nelumbo nucifera Gaertn.; Myr spi, Myriophyllum spicatum $L$. 
analysis was performed to evaluate the correlation between area, volume and maximum lake depth (Zmax), all of which proved to be significantly correlated with each other (Pearson correlation $\mathrm{P}<0.001$ ), as was expected and has previously been demonstrated by several authors (Duarte et al., 1986, and references therein). On the other hand, slope was found to be independent; therefore, we assessed the influence of SD, lake area and slope of the macrophyte-colonized zone on $\mathrm{Zc}$ in the multiple regression analysis. All analyses were performed using PAST 1.97 (Hammer, 2001).

\section{RESULTS}

The majority of the lakes studied are located in the northern of Italy (=15), while a minority of the lakes are in the Southern-Central part of Italy ( $=5$; Fig. 1). Their altitude ranges from 15 to $656 \mathrm{~m}$ a.s.l. The main physico-chemical and morphological features of the investigated lakes are summarized in Tab. 1. The area (A) of the lakes ranges from 0.3 to $370 \mathrm{~km}^{2}$, their volume from about 0.001 to $49 \mathrm{~km}^{3}$, their Zmax from 8.0 to $410 \mathrm{~m}$ and their Zmean (mean depth) from $2.7 \mathrm{~m}$ to $154 \mathrm{~m}$. The total phosphorus concentrations ranged from 6.0 to $123.6 \mu \mathrm{g} \mathrm{L}^{-1}$ (at Monate and Lago Grande, respectively), while the overall alkalinity did not exceed $4124 \mu \mathrm{eq} \mathrm{L} \mathrm{L}^{-1}$, with a minimum of $830 \mu \mathrm{eq} \mathrm{L} \mathrm{L}^{-1}$ at Monate. The maximum littoral slope was observed at Como (83.1\%) and the minimum at the Mantua lakes (4.0\%).

$\mathrm{SD}$ varied between $0.8 \mathrm{~m}$ (Mantua lakes) and $12.8 \mathrm{~m}$ (Bracciano), with a mean value ( \pm standard deviation) of $5.2 \pm 4.0 \mathrm{~m}$; Zc ranged between $3 \mathrm{~m}$ (Alserio) and $26 \mathrm{~m}$

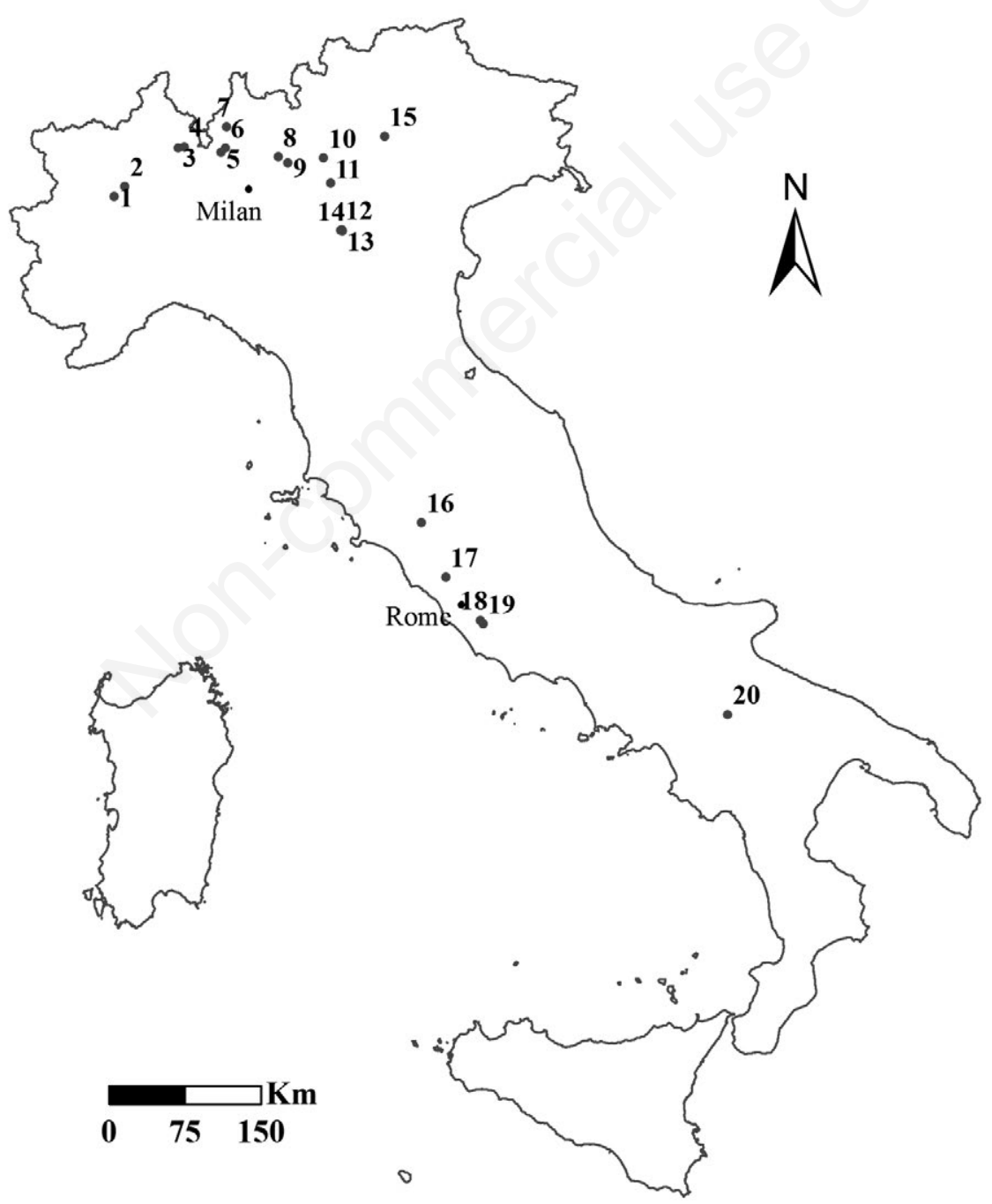

Fig. 1. Location of the lakes considered in the analysis: 1, Candia; 2, Viverone; 3, Monate; 4, Varese; 5, Alserio; 6, Segrino; 7, Como; 8, Endine; 9, Iseo; 10, Idro; 11, Garda; 12, Mantova Superiore; 13, Mantova Mezzo; 14, Mantova Inferiore; 15, Levico; 16, Bolsena; 17, Bracciano; 18, Albano; 19, Nemi; 20, Lago Grande. 
(Bracciano), with a mean value of $8.6 \pm 6.4 \mathrm{~m}$. The deepest plant species were vascular plants (generally Ceratophyllum demersum) for $\mathrm{Zc}<8.5 \mathrm{~m}$, and charophytes at greater depths (Chara globularis between 10 and $20 \mathrm{~m}$ and Nitella opaca between $20 \mathrm{~m}$ and $26 \mathrm{~m}$ ). The linear model analysis revealed three potential correlations between $\mathrm{Zc}$ and SD: a linear correlation, a second order polynomial correlation (quadratic) and a third order polynomial correlation (cubic) (Fig. 2). Although the linear correlation and the quadratic model were statistically significant, it was the cubic correlation that exhibited the lowest AIC value (Tab. 2). This model displays an initial asymptotic trend for $\mathrm{Zc}$ up to $8 \mathrm{~m}$, followed by a slight dip and a subsequent exponential growth. The multiple regression analysis revealed a significant influence of SD and lake area on Zc, whereas the influence of slope was not significant (Tab. 3). On the basis of these results, the model that most appropriately describes the correlation between $\mathrm{Zc}$ (dependent factor), SD and area (independent factors) is represented by the following formula:

$\mathrm{Zc}=1.01 \mathrm{SD}+2.62 \log (\mathrm{A})+1.36$

This model yielded a higher $\mathrm{R}^{2}\left(\mathrm{R}^{2}\right.$ adj $=0.83$; $\mathrm{P}<0.001)$ than the linear model (2), which was based exclusively on the $\mathrm{SD}\left(\mathrm{R}^{2} \operatorname{adj}=0.75 ; \mathrm{P}<0.001\right)$

$$
\mathrm{Zc}=1.39 \mathrm{SD}+1.37
$$

\section{DISCUSSION}

The present study confirms the importance of SD as means of explaining $\mathrm{Zc}$ using a balanced database, i.e. one that is not biased by an overbalance of shallow or deep lakes. Since the majority of the lakes considered in previous studies are shallow (Chambers and Kalff, 1985; Canfield et al., 1985), even those in large datasets (Middelboe and Markager, 1997; Caffrey et al., 2007; Søndergaard et al., 2013), the linear dependence of Zc on SD may have been overestimated. Indeed, few authors have suggested that the relationship between SD and Zc may not be linear. Middleboe and Markager (1997) and Schwarz et al. (2000) reported that the relationship between SD and Zc was asymptotic: as transparency increases, Zc first increases linearly and then follows an asymptotic trend. Similarly, the linear model applied to our data yielded results that are significant but cannot be compared with those yielded by a polynomial model. Consequently, our observations suggest that the $\mathrm{Zc}$ trend is asymptotic at the shallow depths (not exceeding $6 \mathrm{~m}$ at Endine) that are characteristic of small lakes (Fig. 2, on the left of the graph), whilst it is steeper in the larger and deeper lakes (Fig. 2, on the right of the graph). The exponential Zc growth observed for SD values higher than 8 meters could be put in relation with the progressive replacement of vascular species by charophytes with the increase of depth. In fact, it is generally recognized that the species able to reach the maximum growing depth are not vascular, mainly because charophytes are more efficient than vascular plants to capture lights (Hutchinson, 1975).

In the multiple regression analysis performed on our dataset, Zc was significantly affected by lake area. The inclusion of area in the linear model that defines the relationship between SD and Zc improved its prediction accuracy (from $\mathrm{R}^{2}=0.75$ to $\mathrm{R}^{2}=0.83$ ). This is not a surprising finding but confirms the significant influence of lake morphometry
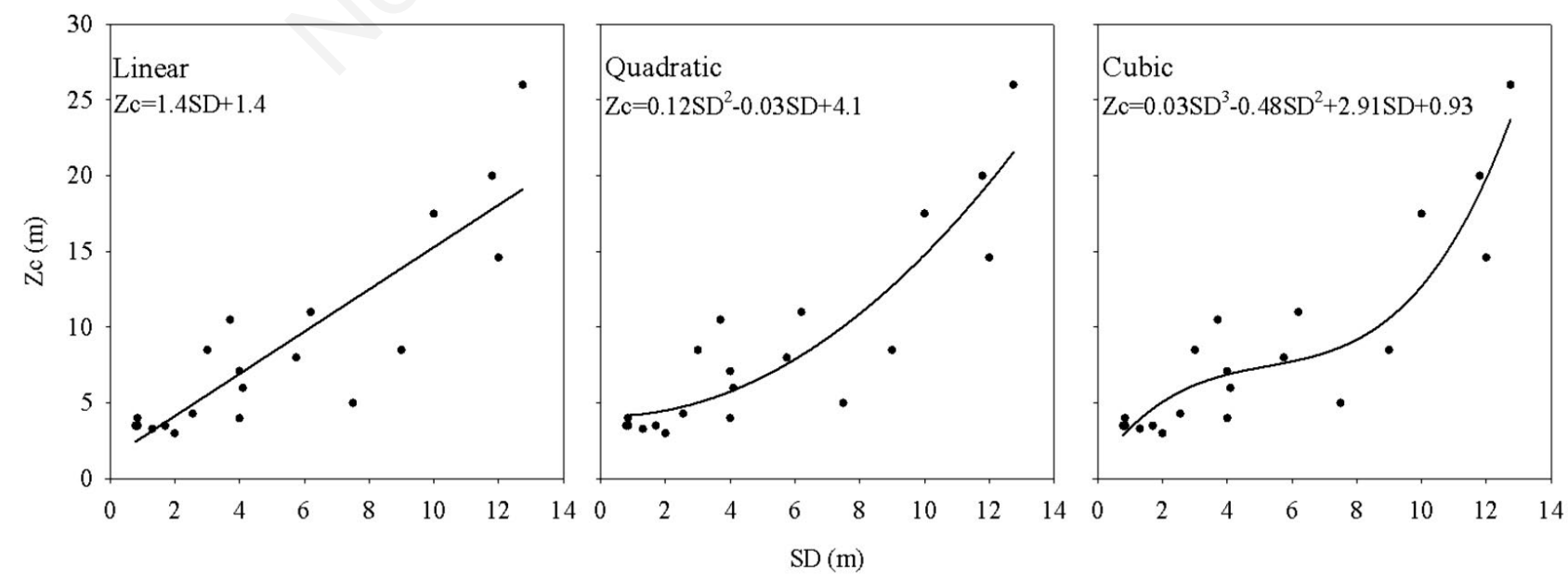

Fig. 2. Linear models used to explain the correlation between Zc (maximum depth of macrophyte colonization) and SD (Secchi disk transparency). The linear model is on the left, the second-order polynomial (quadratic) in the center, and the third-order polynomial (cubic) model on the right. 
on macrophyte spatial arrangement. Similar conclusions were recently reported for macrophyte development in Polish lowland lakes (Kolada, 2014) in agreement with Duarte and Kalff (1990) and Srivastava et al. (1995).

Beyond the pivotal role of light, Sheldon and Boylen (1977) had previously suggested the existence of a relationship between thermocline and $\mathrm{Zc}$ in agreement with the central role played by the morphometric characteristics of a lake in driving important abiotic factors, such as water circulation and thermal conditions (see Bornette and Puijalon, 2011, and references therein). However, the few authors who have collected data on the role played by morphometric characteristics in the spatial arrangement of aquatic plants (Duarte and Kalff, 1986; Duarte et al., 1986; Kolada, 2014) did not examine their influence on $\mathrm{Zc}$ in great detail.

Temperature appears to play an important role in determining the spatial arrangement of submerged plants (Dale, 1986; Bornette and Puijalon, 2011), particularly in deep lakes (Barko et al., 1986). Actually, it is known that i) the thermocline of a lake is correlated with its depth (Hanna, 1990); ii) Zc is correlated to thermocline (Rooney and Kalff, 2000); and iii) macrophytes that survive at the maximum depths of colonization are perennial and can tolerate very low temperatures (Corillion, 1957). For example, some field observations have confirmed that freshwater macrophytes can grow (albeit minimally) below thick layers of ice during wintertime (Boylen and Sheldon, 1976). Nonetheless, if we exclude a limited number of laboratory experiments and in situ observations that have investigated the response of submerged plants to temperature and underwater light regime ( $\mathrm{Ke}$ and $\mathrm{Li}$, 2006; Jarvis and Moore, 2008), hardly any data concerning the relationship between macrophyte depth distribution and temperature exist. Schwarz et al. (2000) have identified the temperature as a secondary factor in modulating the performance of macrophytes, while Middleboe and Markager (1997), and Duarte and Kalff (1987) have considered the latitude as a cofactor in defining Zc.

Temperature affects plant germination in various ways (see, among others Carasso et al., 2012; Pradhan and Badola, 2012). Water temperature exerts a strong influence on macrophyte life phases, such as reproduction, germination and seedling emergence (Barko et al., 1982; Madsen and Adams, 1988; Spencer and Ksander, 1992; Leck, 1996; Xiao et al., 2010). Overall, the onset of germination in freshwater submerged macrophytes has been associated with temperatures ranging between $\sim 23$ and $29^{\circ} \mathrm{C}$ ( $\mathrm{Ke}$ and Li, 2006; Jarvis and Moore, 2008). Moreover, lake thermal conditions can indirectly influence the macrophytes distribution by influencing the vertical stratification of phytoplankton. In fact, thermocline controls the spatial distribution of microalgae and accordingly modulates the transparency of water (Derenbach et al., 1979).
All these findings support the non-negligible role of lake thermal conditions in controlling the distribution of macrophytes. This is especially true for deep lakes of relatively high water clarity or in the stratified ones (Sheldon and Boylen, 1977; Barko et al., 1982). We hold that thermocline is likely to be critical to the depth distribution of macrophytes mainly in deep lakes, influencing both the vertical distribution of phytoplankton and the macrophyte life phases.

\section{CONCLUSIONS}

The findings of the present study thus demonstrate that lake area provides a better understanding of the relationship between SD and Zc. Consequently, we may argue that when SD values are similar, the $\mathrm{Zc}$ of macrophytes in larger lakes tends to be higher. This observation may also have more extensive implications and effects on ecological monitoring programs. The area of lakes can easily be assessed by means of open source GIS systems, and the inclusion of a lake's area in ecological macrophytic multimetric indices (Pall and Moser, 2009; Beck et al., 2010) might help to improve the accuracy of monitoring programs. We believe that the elaboration of macrophytic measurements specifically calibrated according to lake area may lead to a more ef-

Tab. 2. Statistical analysis of the models proposed to describe the correlation between $\mathrm{Zc}$ and SD.

\begin{tabular}{|c|c|c|c|}
\hline & \multicolumn{3}{|c|}{$\mathrm{Zc}=\mathrm{a} 0+\mathrm{a} 3 \mathrm{SD}^{3}+\mathrm{a} 2 \mathrm{SD}^{2}+\mathrm{a} 1 \mathrm{SD}$} \\
\hline & $\begin{array}{l}1^{\text {st }} \text { order } \\
\text { Linear }\end{array}$ & $\begin{array}{l}2^{\text {nd }} \text { order } \\
\text { Quadratic }\end{array}$ & $\begin{array}{c}3^{\text {rd }} \text { order } \\
\text { Cubic }\end{array}$ \\
\hline Chi square & 187.44 & 150.13 & 122.51 \\
\hline $\mathrm{AIC}$ & 192.15 & 157.63 & 133.18 \\
\hline $\mathrm{R}^{2}$ & 0.76 & 0.81 & 0.84 \\
\hline $\mathrm{F}$ & 56.7 & 35.5 & 28.5 \\
\hline $\mathrm{P}$ & $5.7^{-7}$ & $8.4^{-7}$ & $1.2^{-6}$ \\
\hline a & 1.4 & 4.1 & 0.93 \\
\hline b & 1.4 & -0.03 & 2.91 \\
\hline $\mathrm{c}$ & 0 & 0.12 & -0.48 \\
\hline $\mathrm{d}$ & 0 & 0 & 0.03 \\
\hline
\end{tabular}

$\overline{Z c, \text { maximum depth of macrophyte colonization; } S D \text {, Secchi disk trans- }}$ parency.

Tab. 3. Results of multiple regression analysis.

\begin{tabular}{lcccc}
\hline & \multicolumn{4}{c}{ Model Zc=SD+Log A+slope+intercept } \\
& Coeff & Std. err. & T & P \\
\hline Intercept & 1.81 & 1.02 & 87.571 & $<0.1$ \\
SD & 1.07 & 0.20 & 203.897 & $<0.001$ \\
Log A & 2.98 & 0.93 & 126.499 & $<0.05$ \\
Slope & -0.04 & 0.03 & 132.25 & $>0.1$ \\
\hline
\end{tabular}

SD, Secchi disk transparency; A, area. 
fective evaluation of lake conservation status. In conclusion, our data confirm the existence of a polynomial relationship between SD and Zc that highlights the role played by lake area, as opposed to temperature, in driving macrophyte distribution.

Additionally, the use of a balanced dataset appears to avoid the possible interpretative bias due to the use of large dataset that is overbalanced towards small and shallow lakes. Further investigations, based in particular on more extensive databases encompassing larger geographical areas, are warranted to support our results and hypothesis. An expanded analysis might even lead to the inclusion of other potential determinants of macrophyte colonization depth (e.g., north-south gradient).

\section{ACKNOWLEDGMENTS}

We would like to thank the Lombardy Regional Agency for Environmental Protection (ARPA - Lombardia) and the Provincial Agency for Environmental Protection of Trento (APPA) for the data provision, P. Lombardo and L. Baker for revising the English manuscript, and L. Luiselli and S. Leonardi for the statistical advices.

\section{REFERENCES}

Akaike H, 1974. A new look at the statistical model identification. IEEE Trans. Autom. Control 19:716-723.

Azzella MM, Iberite M, Fascetti S, Rosati L, 2013a. Loss detection of aquatic habitats in italian volcanic lakes using historical data. Plant. Bios. 147:521-524.

Azzella MM, Ricotta C, Blasi C, 2013b. Aquatic macrophyte diversity assessment: Validation of a new sampling method for circular-shaped lakes. Limnologica 43:492-499.

Azzella MM, Rosati L, Iberite M, Bolpagni R, Blasi C, 2014. Changes in aquatic plants in the Italian volcanic-lake system detected using current data and historical records. Aquat. Bot. 112:41-47.

Barko J, Hardin D, Matthews M, 1982. Growth and morphology of submersed freshwater macrophytes in relation to light and temperature. Can. J. Bot. 60:877-887.

Barko J, Adams M, Clesceri N, 1986. Environmental factors and their consideration in the management of submersed aquatic vegetation: a review. J. Aquat. Plant. Manage. 24:1-10.

Bazzichelli G, Abdelahad N, 2009. Flora analitica delle Caroficee. Università degli studi di Roma La Sapienza, Roma: 75 pp.

Beck MW, Hatch LK, Vondracek B, Valley RD, 2010. Development of a macrophyte-based index of biotic integrity for Minnesota lakes. Ecol. Indic. 10:968-979.

Boylen CW, Sheldon RB 1976. Submergent macrophytes: growth under winter ice cover. Science 194:841-842.

Bolpagni R, 2013. Multimetric indices based on vegetation data for assessing ecological and hydromorphological quality of a man-regulated lake. Ann. Bot. 3:87-95.

Bolpagni R, Bartoli M, Viaroli P, 2013a. Species and functional plant diversity in a heavily impacted riverscape: implications for threatened hydro-hygrophilous flora conservation. Limnologica 43:230-238.
Bolpagni R, Bettoni E, Bonomi F, Bresciani M, Caraffini K, Costaraoss S, Giacomazzi F, Monauni C, Montanari P, Mosconi MC, Oggioni A, Pellegrini G, Zampieri C, 2013b. Charophytes of Garda lake (Northern Italy): a preliminary assessment of diversity and distribution. J. Limnol. 72:388393.

Bolpagni R, Bresciani M, Laini A, Pinardi M, Matta E, Ampe E, Giardino C, Viaroli P, Bartoli M, 2014. Remote sensing of phytoplankton-macrophyte coexistence in shallow hypereutrophic fluvial lakes. Hydrobiologia DOI: 10.1007/ s10750-013-1800-6.

Bolpagni R, Pierobon E, Bartoli M, Nizzoli D, Tomaselli M, Viaroli P, 2007. Diurnal exchanges of $\mathrm{CO} 2$ and $\mathrm{CH} 4$ across the water-atmosphere interface in a water chestnut meadow (Trapa natans L.). Aquat. Bot. 87:3-48.

Bornette G, Puijalon S, 2011. Response of aquatic plants to abiotic factors: a review. Aquat. Sci. 73: 1-14.

Caffrey AJ, Hoyer MV, Canfield Jr DE, 2007. Factors affecting the maximum depth of colonization by submersed macrophytes in Florida lakes. Lake Reserv. Manage. 23:287-297.

Canfield D, Langeland K, Linda S, Haller W, 1985. Relations between water transparency and maximum depth of macrophyte colonization in lakes. J. Aquat. Plant. Manage. 23:25-28.

Carasso V, Fusconi A, Hay FR, Dho S, Gallino B, Mucciarelli M, 2012. A threatened alpine species, Fritillaria tubiformis subsp. moggridgei: Seed morphology and temperature regulation of embryo growth. Plant. Bios. 146:74-83.

Carpenter SR, Lodge DM, 1986. Effects of submersed macrophytes on ecosystem processes. Aquat. Bot. 26:341-370.

Carvalho L, Solimini AG, Phillips G, Pietilainen O-P, Moe J, Cardoso AC, Solheim AL, Ott I, Søndergaard M, Tartari G, Rekolainen S, 2009. Site-specific chlorophyll reference conditions for lakes in Northern and Western Europe. Hydrobiologia 633:59-66.

Chambers PA, Kalff J, 1985. Depth distribution and biomass of submersed aquatic macrophyte communities in relation to Secchi depth. Can. J. Fish. Aquat. Sci. 42:701-709.

Conti F, Abbate G, Alessandrini A, Blasi C, 2005. An annotated checklist of the Italian vascular flora. Palombi Ed., Rome: 420 pp.

Corillion R, 1957. [Les charophycées de France et d'Europe Occidentale].[Book in French]. Trav. Lab. Fac. Sc., Angers: 499 pp.

Dale H, 1986. Temperature and light: the determining factors in maximum depth distribution of aquatic macrophytes in Ontario, Canada. Hydrobiologia 133:73-77.

Derenbach JB, Astheimer H, Hansen HP, Leach H, 1979. Vertical microscale distribution of phytoplankton in relation to the thermocline. Mar. Ecol.-Prog. Ser 1:187-193.

Duarte CM, Kalff J, 1986. Littoral slope as a predictor of the maximum biomass of submerged macrophyte communities. Limnol. Oceanogr. 31:1072-1080.

Duarte CM, Kalff J, 1987. Latitudinal influences on depths of maximum colonization and maximum biomass of submerged angiosperms in lakes. Can. J. Fish. Aquat. Sci. 44:1759-1764.

Duarte CM, Kalff J, 1990. Patterns in the submerged macrophyte biomass of lakes and the importance of the scale of analysis in the interpretation. Can. J. Fish. Aquat. Sci. 47:357-363. 
Duarte CM, Kalff J, Peters RH, 1986. Patterns in biomass and cover of aquatic macrophytes in lakes. Can. J. Fish. Aquat. Sci. 43:1900-1908.

Dudgeon D, Arthington AH, Gessner MO, Kawabata ZI, Knowler DJ, Leveque C, Naiman RJ, Prieur-Richard AH, Soto D, Stiassny MLJ, Sullivan CA, 2006. Freshwater biodiversity: importance, threats, status and conservation challenges. Biol. Rev. 81:163-182.

Hammer Ø, Harper DA, Ryan PD, 2001. PAST: Paleontological statistics software package for education and data analysis. Palaeontol. Electronica 4:9.

Hanna M, 1990. Evaluation of models predicting mixing depth. Can. J. Fish. Aquat. Sci. 47:940-947.

Hudon C, Lalonde S, Gagnon P, 2000. Ranking the effects of site exposure, plant growth form, water depth, and transparency on aquatic plant biomass. Can. J. Fish. Aquat. Sci. 57:31-42.

Hutchinson G, 1975. A treatise on limnology: limnological botany, 3. Wiley \& Sons, New York: 660 pp.

Jarvis JC, Moore KA, 2008. Influence of environmental factors on Vallisneria americana seed germination. Aquat. Bot. 88:283-294.

Ke X, Li W, 2006. Germination requirement of Vallisneria natans seeds: implications for restoration in Chinese lakes. Hydrobiologia 599:357-362.

Kolada A, 2014. The effect of lake morphology on aquatic vegetation development and changes under the influence of eutrophication. Ecol. Indic. 38:282-293.

Leck MA, 1996. Germination of macrophytes form a Delawarer River tidal freshwater wetland. Bull. Torrey Bot. Club 123:48-67.

Madsen JD, Adams MS, 1988. The germination of Potamogeton pectinatus tubers: environmental control by temperature and light. Can. J. Bot. 66:2523-2526.

Middelboe AL, Markager S, 1997. Depth limits and minimum light requirements of freshwater macrophytes. Freshwater Biol. 37:553-568.

Oggioni A, Buzzi F, Bolpagni R, 2013. [Indice macrofitico MacroIMMI per la valutazione della qualità ecologica dei laghi], p. 45-74. In: AA.VV. (eds.), [Indici per la valutazione della qualità ecologica dei laghi].[Report in Italian]. Report CNR - ISE, 03-11, Verbania-Pallanza, Italy.

Pall K, Moser V, 2009. Austrian Index Macrophytes (AIM-Module 1) for lakes: a Water Framework Directive compliant assessment system for lakes using aquatic macrophytes. Hydrobiologia 633:83-104.

Pradhan BK, Badola HK, 2012. Effects of microhabitat, light and temperature on seed germination of a critically endangered Himalayan medicinal herb, Swertia chirayita: Conservation implications. Plant. Bios. 146:345-351.

Rooney N, Kalff J, 2000. Inter-annual variation in submerged macrophyte community biomass and distribution: the influence of temperature and lake morphometry. Aquat. Bot. 68:321-335.

Sayer CD, Burgess A, Kari K, Davidson TA, Peglar S, Yang HD, Rose N, 2010. Long-term dynamics of submerged macrophytes and algae in a small and shallow, eutrophic lake: implications for the stability of macrophyte-dominance. Freshwater Biol. 55:565-583.

Scheffer M, Szabo S, Gragani A, Van Nes EH, Rinaldi S, Kautsky N, Norberg J, Roijackers RMM, Franken RJM, 2003. Floating Plant Dominance as a Stable State. PNAS 100:4040-4045

Schmieder K, 2004. European lake shores in danger - concepts for a sustainable development. Limnologica 34:3-14.

Schwarz AM, Howard-Williams C, Clayton J, 2000. Analysis of relationships between maximum depth limits of aquatic plants and underwater light in 63 New Zealand lakes. New Zeal. J. Mar. Fresh. 34:157-174.

Sheldon RB, Boylen CW, 1977. Maximum depth inhabited by aquatic vascular plants. Am. Midl. Nat. 97:248-254.

Søndergaard M, Phillips G, Hellsten S, Kolada A, Ecke F, Mäemets H, Mjelde M, Azzella MM, Oggioni A, 2013. Maximum growing depth of submerged macrophytes in European lakes. Hydrobiologia 704:165-177.

Spears BM, Gunn IDM, Carvalho L, Winfield IJ, Dudley B, Murphy K, May L, 2009. An evaluation of methods for sampling macrophyte maximum colonisation depth in Loch Leven, Scotland. Aquat. Bot. 91:75-81.

Spencer DF, Ksander GG, 1992. Influence of temperature and moisture on vegetative propagule germination of Potamogeton species: implication for aquatic plant management. Aquat. Bot. 43:351-364.

Srivastava SD, Staicer CA, Freedman B, 1995. Aquatic vegetation of Nova Scotian lakes differing in acidity and trophic status. Aquat. Bot. 51:181-196.

Tombolini I, Caneva G, Cancellieri L, Abati S, Ceschin S, 2014. Damming effects on riparian and aquatic vegetation: the Nazzano case study (Tiber River, central Italy). Knowl. Manag. Aquat. Ec. DOI: 10.1051/kmae/2013085.

Xiao C, Wang X, Xia J, Liu G, 2010. The effect of temperature, water level and burial depth on seed germination of Myriophyllum spicatum and Potamogeton malaianus. Aquat. Bot. 92:28-32. 